\title{
Quality and shelf life of the gonad of lion's paw scallop transported and stored whole in refrigeration
}

\author{
Qualidade e vida de prateleira da gônada do bivalve pata de leão, transportado e armazenado \\ inteiramente em refrigeração
}

\author{
Victor Manuel Ocaño-Higuera ${ }^{\mathrm{I}}$ Nathaly Montoya-Camacho ${ }^{\mathrm{I}}$ Enrique Marquez-Rios ${ }^{\mathrm{II}}$ \\ Maria Teresa Sumaya-Martinez ${ }^{\text {III }}$ Leticia Monica Sanchez-Herrera ${ }^{\text {III }}$ Rosendo Balois-Morales $^{\text {III }}$ \\ Francisco Javier Castillo-Yañez ${ }^{\mathrm{I}}$ Gerardo Navarro-Garcia $^{\mathrm{IV}}$ Alfonso Nivardo Maeda Martínez $^{\mathrm{V}}$ \\ Edgar Ivan Jimenez-Ruiz ${ }^{\text {II* }}$
}

\begin{abstract}
The effect of refrigerated $48 \mathrm{~h}$ transport and 4 days storage on the quality and shelf life of the whole lion's paw scallop Nodipecten subnodosus gonad was evaluated. Proximal composition, adenosine 5'triphosphate (ATP) and related products, $K$-value, total volatile bases $(T V B-N)$, trimethylamine (TMA-N), pH, fatty acid profile and microbiological analyses were quantified. Gonad holds a significant composition of essential fatty acids while levels of gonadal ATP were initially low; moreover, $K$-value of the gonad remained constant. With respect to TVB-N and TMA-N, only the former exceeded allowed limits. The $p H$ level showed no significant variation during storage and, despite the high level of TVB-N, according to the TMA-N as well as microbiological analyses it was demonstrated innocuity after 4 days under the transportation and storage conditions utilized.
\end{abstract}

Key words: lion's paw scallop, Nodipecten subnodosus, quality, shelf life, gonad.

\section{RESUMO}

Avaliou-se o efeito do transporte em refrigeração por 48 horas e quatro dias de armazenamento sobre a qualidade e vida de prateleira da gônada do bivalve pata de leão, Nodipecten subnodosus. Determinou-se a composição centesimal, a adenosina 5 trifosfato (ATP) e afins, o indice $K$, bases voláteis totais $(T V B-N)$, trimetilamina (TMA-N), $p H$, perfil de ácidos graxos e análise microbiológica. A Gônada apresentou uma importante composição de ácidos graxos essenciais e baixos níveis iniciais de ATP, enquanto o indice $K$ manteve-se constante. Quanto a TVB -N e TMA- $N$, apenas as primeiras ultrapassaram os limites admissiveis. Os valores de pH não mostraram nenhuma mudança significativa durante o armazenamento e, apesar dos altos niveis de TVB -N, de acordo com a análise quantitativa e microbiológica TMA- N, a segurança do produto foi demonstrada após quatro dias sob as condições de transporte e armazenamento utilizado.

Palavras-chave: vieira pata de leão, Nodipecten subnodosus, qualidade, vida de prateleira, gônada.

\section{INTRODUCTION}

The lion's paw scallop Nodipecten subnodosus constitutes one of the most important fishery resources on Mexico's Baja California Peninsula. While in both Mexico and the United States the principal product consumed is the freshrefrigerated adductor muscle, other countries, mainly in Asia and Europe, require a high demand for whole bivalves on the shell. Those products are usually consumed after being cooked in their shells, but are also served raw in dishes of the sushi or sashimi type. In other cases, the adductor muscle is served together with the gonad (PAUST \& RICE, 2001). With regards to the gonad, it is important to point out its high proportion of essential fatty acids (RACOTTA et al., 2008), including such as omega 3 polyunsaturated fatty acids as eicosapentaenoic (EPA) and docosahexaenoic (DHA), which cannot be synthesized by the human organism and, therefore,

'Departamento de Ciencias Químico Biológicas, Universidad de Sonora (UNISON), Hermosillo, Sonora, México.

IIDepartamento de Investigación y Posgrado en Alimentos, UNISON, Hermosillo, Sonora, México.

III Unidad de Tecnología de Alimentos, Secretaría de Investigación y Posgrado, Universidad Autónoma de Nayarit (UAN), Ciudad de la

Cultura “Amado Nervo", Blvd, Tepic-Xalisco S/N, CP 63155, Tepic, Nayarit, Mexico. E-mail: jiru80@gmail.com.*Corresponding author.

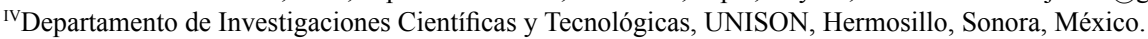

${ }^{\mathrm{v}}$ Centro de Investigaciones Biológicas del Noroeste, S.C., La Paz, B.C.S., Mexico. 
must be obtained directly from elements of the diet. It has been shown that consuming these types of fatty acids brings numerous health benefits (CASTRO-GONZÁLEZ, 2002). This demonstrates the importance of promoting the consumption of this kind of natural compound, which can also confer aggregate value or increase the attractiveness of the products obtained from the gonad of pectinid species like N. subnodosus (OCAÑO-HIGUERA et al., 2001).

At present, there is no feasible and established strategy for exporting and distributing this particular pectinid in its whole, fresh-refrigerated presentation. In practice, handlers strive to maintain the cold chain right from the moment when the organisms are harvested until they are processed and/or consumed, but this is not always achieved. Therefore, it is necessary to look for and design alternative storage methods during transport and distribution that will assure that quality and innocuity of the product will be maintained until it is offered to the consumer. Postmortem biochemical changes that impact the quality and shelf life of finished product can be studied by monitoring parameters and indicators of quality and freshness (SIKORSKI et al., 1990). Thus, the objective of this study was to evaluate the quality and shelf life of the gonad of whole lion's paw scallops during refrigerated transport and storage, as a possible alternative for exporting the product to international markets, when this organ attached to the muscle and/or other organ, depending on the type of product being handled.

\section{MATERIALS AND METHODS}

\section{Experimental organisms}

Adult organisms of lion's paw scallops, $\mathbf{N}$. subnodosus, with a height of approximately $10 \mathrm{~cm}$ were utilized, after being harvested from a culture system located in Bahía Tortugas, Baja California Sur, in the month of June, 2009. Before transport and storage, the scallops were cleaned with an oyster machine that functions on the basis of sprayers and brushes (ETS BERTRAND, Marennes, France). The cleaning process was completed with the specimens being brushed by hand and then cleared in 200-L fiberglass tanks for $1 \mathrm{~h}$.

\section{Experiment on transport and storage}

Prior to transport, organisms were placed in coolers made of expanded polystyrene with a volume of 45L. A total of 120 live organisms were arranged dorsal-ventrally with elastic bands attached (to prevent them from opening their valves and possibly drying out), and distributed into two coolers. During the packing process, the scallops were placed in a horizontal position and a bed of brown paper moistened with seawater was placed between the layers of mollusks. Once the organisms were packed, and just before sealing the coolers, $5 \mathrm{~kg}$ of frozen refrigerant gel at $-20^{\circ} \mathrm{C}$ was introduced (Dolphin Blue Crabs, SA de CV) and a thermograph was placed to monitor the internal temperature of the coolers during the period of transport. The refrigerant gel was separated from the upper layer of scallops by another bed of moistened brown paper. At that moment, the gonads of six scallops were frozen in liquid nitrogen to be used to determine the initial biochemical conditions at the time of transport.

Transportation was simulated under the most realistic conditions possible. In the first phase, the coolers with the refrigerant gel and the scallops were carried in a pick-up truck at ambient $\left(22.9 \pm 4.4^{\circ} \mathrm{C}\right)$ temperature for $14 \mathrm{~h}$. Then, a second stage of transportation was simulated, in which the sealed coolers were placed in a refrigerated room at the installations of CIBNOR, La Paz, B.C.S. This procedure was meant to simulate the second stage of transportation; i.e., when the organisms are transported in refrigerated trucks. The total simulated transportation time was $48 \mathrm{~h}$. This simulation of the stages of transportation was designed in accordance with what are assumed to be the conditions necessary to deliver this product to an international market, in this case, United States. In this 48 -h experiment the mean temperature was $4.7 \pm 1.7^{\circ} \mathrm{C}$.

In the last phase, the organisms were removed from the coolers and placed in refrigerated storage in polyethylene bags to simulate the actual storage facilities utilized by the final receiver, who would then undertake to sell the product. At that moment, the gonads of six organisms were dissected and frozen in liquid nitrogen for later determination of the effects of transportation and to establish the quality and shelf life at day 0 . Finally, a thermograph was placed to monitor the temperature of the refrigerated room throughout product storage, which showed a mean value of $4.5 \pm 0.9^{\circ} \mathrm{C}$ during this 4 -days storage stage.

Sampling strategy used in the study of refrigeration The organisms transported under the simulated conditions described above remained in the refrigerated storage area for a period of 4 days, which is the commonly used time to market for 
these products (MAEDA-MARTINEZ, personal communication, 2009). During this time, the gonads of six organisms were collected, dissected, and frozen in liquid nitrogen every $24 \mathrm{~h}$, and then stored at $-86^{\circ} \mathrm{C}$ until their analysis. At each point of the sampling program, $\mathrm{pH}$, the K-value, total volatile bases (TVB-N) and trimethylamine (TMA-N) were monitored. Additionally, due to the high concentration of lipids found in the gonad (in contrast to the adductor muscle, which is considered lean), analyses of the fatty acid profile was conducted to determine their composition and nutritional value. In this determination, only samples from organisms obtained directly from the lagoon (initial), from day 0 (post-transport), and from day 4 (the final day of refrigerated storage) were utilized. Similarly, throughout the storage period, microbiological analyses were conducted in order to determine whether or not the gonads were apt for human consumption. In this procedure, all of the organisms' moist tissues were extracted and homogenized together with intervalvular liquid.

Proximal analysis

Quantification of the moisture, protein, lipid, carbohydrate and ash content of both the gonad were carried out following the methodologies described in the AOAC (2002).

Determination and quantification of fatty acids

The fatty acid profile was determined through gas chromatography (GC), following the methodology reported by DE LEONARDIS \& MACCIOLA (2003), utilizing a mixture of commercial standards as reference.

$\mathrm{pH}$

The determination of $\mathrm{pH}$ was conducted following the technique established by WOYEWODA et al. (1986). A Orion 420 potentiometer (Termo Electron Corp.) was used.

ATP, products of its breakdown, and the K-value

The identification and quantification of the adenosine 5 'triphosphate (ATP) and the products of its breakdown in the gonad were conducted through high resolution liquid chromatography. In this procedure, the methodology described by RYDER (1985) was followed. K-value was calculated according to the equation described by SAITO et al. (1959): K-value $(\%)=[(\mathrm{HxR}+\mathrm{Hx}) /$ $(\mathrm{ATP}+\mathrm{ADP}+\mathrm{AMP}+\mathrm{IMP}+\mathrm{HxR}+\mathrm{Hx})](100)$

where: ATP $=$ adenosine 5 'triphosphate, $\mathrm{ADP}=$ adenosine 5 'diphosphate, $\mathrm{AMP}=$ adenosine 5'monophosphate, IMP = inosine 5'monophosphate, $\mathrm{HxR}=$ inosine and $\mathrm{Hx}=$ hypoxanthine

TVB-N and TMA-N

The determinations of TVB-N and TMA-N were conducted following the methodology described by WOYEWODA et al. (1986).

Microbiological analyses

Microbiological analyses were carried out every $24 \mathrm{~h}$ for 4 days, following the methodologies defined in the NOM-031-SSA1-1993 norm. A total of six organisms were collected every $24 \mathrm{~h}$. The moist tissues were extracted from the scallops and homogenized to obtain a representative sample and the amounts of fecal coliforms and aerobic bacteria were determined. Also, samples were taken to be analyzed for Vibrio cholerae and Salmonella spp. (6 whole organisms) at days 1 and 4 of refrigerated storage.

\section{Statistical analysis}

Using the results obtained, a one-way variance analysis (ANOVA) was conducted. When significant differences were found, the Tukey multiple comparison test was applied using the NCSS Ver. 2000 program (HINTZE, 2001). Also, in some cases regression and lineal correlation analyses were performed. A significance level of 5\% was set for all of the analyses conducted.

\section{RESULTS}

Proximal analysis and quantification of fatty acids

The proximate composition of the gonad was $77.34 \pm 0.54 \%$ moisture, $15.09 \pm 0.57 \%$ protein, $6.74 \pm 1.13 \%$ lipids, $0.06 \pm 0.01 \%$ carbohydrates, and $1.68 \pm 0.25 \%$ ash. Moreover, table 1 shows the results of the lipid profile corresponding to some of the most representative fatty acids, of either the saturated, mono- or poly-unsaturated types. It is clear that of all the fatty acids quantified only the stearic, oleic, and arachidic types were affected in the transport phase or during storage $(\mathrm{P}<0.05)$. It is important to mention that considerable amounts of EPA and DHA were found, which represent the most important essential omega 3 acids, and that they were not affected during either refrigerated transport or storage $(\mathrm{P}>0.05)$.

$\mathrm{pH}$

Table 1 presents the data on the $\mathrm{pH}$ of the gonad of the lion's paw scallop transported in 


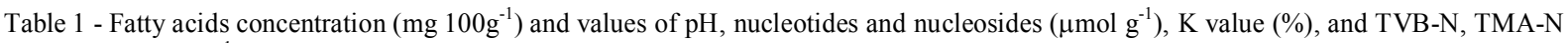

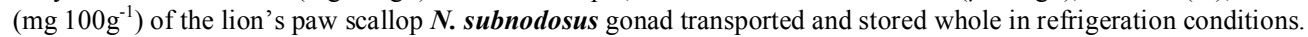

\begin{tabular}{|c|c|c|c|c|c|c|}
\hline \multirow{2}{*}{$\begin{array}{l}\text { Fatty acid* or } \\
\text { Parameter** }\end{array}$} & \multirow{2}{*}{$\begin{array}{l}\text { Initial } \\
\text { Organisms }\end{array}$} & \multirow{2}{*}{$\begin{array}{l}\text { Pos-transport } \\
\text { (Day 0) }\end{array}$} & \multicolumn{4}{|c|}{ 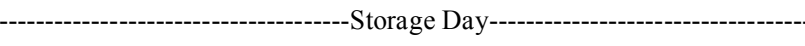 } \\
\hline & & & 1 & 2 & 3 & 4 \\
\hline Palmitic (C:16:0) & $580 \pm 140^{\mathrm{a}}$ & $670 \pm 170^{\mathrm{a}}$ & ND & ND & ND & $450 \pm 90^{\mathrm{a}}$ \\
\hline Palmitoleic (C16:1) & $220 \pm 50^{\mathrm{a}}$ & $200 \pm 70^{\mathrm{a}}$ & ND & ND & ND & $170 \pm 70^{\mathrm{a}}$ \\
\hline Estearic (C18:0) & $360 \pm 50^{\mathrm{a}}$ & $260 \pm 60^{\mathrm{ab}}$ & ND & ND & ND & $190 \pm 40^{\mathrm{b}}$ \\
\hline Oleic $(\mathrm{C} 18: 1)$ & $600 \pm 70^{\mathrm{a}}$ & $220 \pm 50^{\mathrm{b}}$ & ND & ND & ND & $140 \pm 10^{\mathrm{b}}$ \\
\hline Arachidic (C20:0) & $780 \pm 50^{\mathrm{a}}$ & $130 \pm 30^{\mathrm{b}}$ & ND & ND & ND & $140 \pm 20^{\mathrm{b}}$ \\
\hline Behenic (C22:0) & $120 \pm 10^{\mathrm{a}}$ & $100 \pm 60^{\mathrm{a}}$ & ND & ND & ND & $60 \pm 20^{\mathrm{a}}$ \\
\hline$(\mathrm{EPA}, \mathrm{C} 20: 5)$ & $110 \pm 5^{\mathrm{a}}$ & $120 \pm 90^{\mathrm{a}}$ & ND & ND & ND & $100 \pm 30^{\mathrm{a}}$ \\
\hline (DHA, C22:6) & $140 \pm 10^{\mathrm{a}}$ & $150 \pm 40^{\mathrm{a}}$ & ND & ND & ND & $140 \pm 40^{\mathrm{a}}$ \\
\hline $\mathrm{pH}$ & $7.11 \pm 0.12^{\mathrm{a}}$ & $6.90 \pm 0.15^{\mathrm{a}}$ & $6.83 \pm 0.18^{\mathrm{a}}$ & $6.44 \pm 0.24^{\mathrm{b}}$ & $6.83 \pm 0.18^{\mathrm{a}}$ & $6.98 \pm 0.14^{\mathrm{a}}$ \\
\hline ATP & $0.09 \pm 0.04^{\mathrm{ab}}$ & $0.07 \pm 0.03^{\mathrm{bc}}$ & $0.14 \pm 0.04^{\mathrm{a}}$ & $0.04 \pm 0.02^{\mathrm{bc}}$ & $0.02 \pm 0.02^{\mathrm{c}}$ & $0.07 \pm 0.03^{\mathrm{bc}}$ \\
\hline $\mathrm{ADP}$ & $0.20 \pm 0.08^{\mathrm{a}}$ & $0.13 \pm 0.10^{\mathrm{a}}$ & $0.06 \pm 0.06^{\mathrm{a}}$ & $0.12 \pm 0.06^{\mathrm{a}}$ & $0.11 \pm 0.04^{\mathrm{a}}$ & $0.11 \pm 0.03^{\mathrm{a}}$ \\
\hline AMP & $0.21 \pm 0.14^{\mathrm{a}}$ & $0.25 \pm 0.25^{\mathrm{a}}$ & $0.30 \pm 0.16^{\mathrm{a}}$ & $0.24 \pm 0.12^{\mathrm{a}}$ & $0.16 \pm 0.05^{\mathrm{a}}$ & $0.12 \pm 0.09^{\mathrm{a}}$ \\
\hline IMP & $0.43 \pm 0.13^{\mathrm{a}}$ & $0.41 \pm 0.24^{\mathrm{a}}$ & $0.32 \pm 0.04^{\mathrm{a}}$ & $0.35 \pm 0.04^{\mathrm{a}}$ & $0.34 \pm 0.05^{\mathrm{a}}$ & $0.11 \pm 0.05^{\mathrm{b}}$ \\
\hline HxR & $0.92 \pm 0.24^{\mathrm{a}}$ & $0.94 \pm 0.19^{\mathrm{a}}$ & $0.93 \pm 0.23^{\mathrm{a}}$ & $0.85 \pm 0.16^{\mathrm{a}}$ & $0.89 \pm 0.24^{\mathrm{a}}$ & $0.45 \pm 0.26^{\mathrm{b}}$ \\
\hline $\mathrm{Hx}$ & $0.15 \pm 0.04^{\mathrm{c}}$ & $0.15 \pm 0.03^{\mathrm{c}}$ & $0.19 \pm 0.05^{\mathrm{bc}}$ & $0.29 \pm 0.05^{\mathrm{ab}}$ & $0.33 \pm 0.06^{\mathrm{a}}$ & $0.39 \pm 0.09^{\mathrm{a}}$ \\
\hline $\mathrm{K}$ value & $54.10 \pm 10.2^{\mathrm{a}}$ & $56.30 \pm 5.02^{\mathrm{a}}$ & $57.91 \pm 10.29^{\mathrm{a}}$ & $60.83 \pm 5.09^{\mathrm{a}}$ & $66.50 \pm 3.71^{\mathrm{a}}$ & $67.43 \pm 8.08^{\mathrm{a}}$ \\
\hline TBV-N & $24.15 \pm 4.12^{\mathrm{b}}$ & $24.41 \pm 4.02^{\mathrm{b}}$ & $20.96 \pm 0.07^{\mathrm{b}}$ & $27.79 \pm 0.11^{\mathrm{b}}$ & $44.08 \pm 4.06^{\mathrm{a}}$ & $41.63 \pm 0.28^{\mathrm{a}}$ \\
\hline TMA-N & $1.41 \pm 0.02^{\mathrm{a}}$ & $1.40 \pm 0.10^{\mathrm{a}}$ & $1.46 \pm 0.04^{\mathrm{a}}$ & $1.43 \pm 0.07^{\mathrm{a}}$ & $1.41 \pm 0.09^{\mathrm{a}}$ & $1.46 \pm 0.03^{\mathrm{a}}$ \\
\hline
\end{tabular}

ND: No Determined.

*Values are mean and standard deviation of $n=3$.

**Values are mean and standard deviation of $n=6$.

Means in the same row with different superscript letters are statistically different $(\mathrm{P}<0.05)$

immersion and stored whole in refrigeration. A significant reduction $(\mathrm{P}<0.05)$ can be seen at day 2 of refrigerated storage, though after it remained practically without change $(\mathrm{P}>0.05)$.

ATP, products of its breakdown, and the K-value

The results for ATP and products from its breakdown in the gonad of the lion's paw scallop are shown in table 1. For ATP concentration, during storage an increase was seen on day $1(\mathrm{P}<0.05)$, but it decreased on day 2 and continued with no further significant change until the end of the storage period $(\mathrm{P}>0.05)$. Regarding ADP initial concentration, during storage it remained without significant change until the end of the experiment $(\mathrm{P}>0.05)$. Both AMP and IMP remained practically constant during the entire experiment $(\mathrm{P}>0.05)$, with the exception of day 4 , when a decrease of IMP was observed $(\mathrm{P}<0.05)$. During storage, HxR decreased up to the last day, while $\mathrm{Hx}$ increased on day $2(\mathrm{P}<0.05)$, but then both remained without significant variation until the end of the experiment $(\mathrm{P}>0.05)$. With respect to the $\mathrm{K}$-value, table 1 shows the results obtained from the gonad of N. subnodosus stored in refrigeration. The K-values were not affected during the simulated transport or storage, and showed no significant change throughout the experiment $(\mathrm{P}>0.05)$.

\section{TVB-N and TMA-N}

Table 1 shows the TVB-N and TMA-N values for the gonad of lion's paw scallop $\boldsymbol{N}$. subnodosus transported in immersion and stored whole in refrigerated conditions. The initial values observed for TVB-N were very high in the organisms obtained directly from the culture site. Later, an increase was seen at days 2 and $3(\mathrm{P}<0.05)$, but no further change was noted up to the end of the storage period. On the other hand, TMA-N values remained

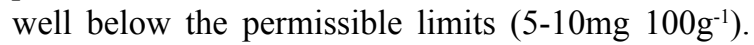
The initial value found was $1.4 \pm 0.01 \mathrm{mg}_{100 \mathrm{~g}^{-1} \text { and }}$ no significant variation was observed during storage $(\mathrm{P}>0.05)$.

\section{Microbiological analyses}

According to the results of the microbiological analyses, the count of mesophilic aerobic bacteria on different days of storage (final value of $3.49 \times 10^{5} \mathrm{CFU} \mathrm{g}^{-1}$ at day 4) never reached the maximum limit of $5 \times 10^{5} \mathrm{CFU} \mathrm{g}^{-1}$ that is allowed for human consumption (NOM-031-SSA1-1993) 
at any moment of the experiment. As in the case of mesophilic aerobic, the fecal coliform bacteria did not reach the maximum limit (30MPN $100 \mathrm{~g}^{-1}$ ) indicated by the norm, on any of the sampling days, with a final value of $40 \mathrm{MPN} 100 \mathrm{~g}^{-1}$ at day 4 .

Other important bacteria that must be determined and controlled according to the NOM031-SSA1-1993 norm are the species $\boldsymbol{V}$. cholerae and Salmonella spp. In these two cases, the requirements establish a zero tolerance level for all products of this type. In this experiment, the samples analyzed on day 1 and day 4 showed no presence of these bacteria; thus, the product does not represent a risk for consumers.

\section{DISCUSSION}

The percentage of moisture in the gonad was less than the figure reported for this species and other pectinids by PALACIOS et al. (2005) and RACOTTA et al. (2008). This tissue is also characterized by the presence of high protein content; and the high lipid concentration may be due to the fact that the gonad serves as the main lipids reserve to be used during reproduction. Moreover, the organisms were collected in the month of June, a period in which their gametogenic cycle is in full bloom in this region of Mexico's Baja California peninsula (RACOTTA et al., 2008). Otherwise, the amount of carbohydrates found in the gonad was below that reported by both PALACIOS et al. (2005) and RACOTTA et al. (2008) for the same species, but at a different culture site and that TSUJI \& NISHIDA (1988) found for the pectinid Patinopecten yessoensis. Upon comparing this component with the composition normally found in the muscle (PALACIOS et al., 2005; RACOTTA et al., 2008), the gonad showed lower amounts, as occurs in most of these species. Respect to ash content, there are no reports for this component in gonad of this pectinid or any other similar species.

On the other hand, the concentrations of EPA+DHA found in the gonad of the lion's paw scallop exceeded the amounts that are recommended $(200 \mathrm{mg}$ $\left.\mathrm{d}^{-1}\right)$ to obtain health benefits from the consumption of these compounds. Moreover, these concentrations of EPA+DHA (240-270mg $\left.100 \mathrm{~g}^{-1}\right)$ are slightly below the $300 \mathrm{mg}$ reported in supplements derived from encapsulated marine oils that are considered nutraceutical (CASTRO-GONZÁLEZ, 2002).

The $\mathrm{pH}$ reduction at day 2 possibly was due to the production of lactic acid in anaerobic conditions. However, the gonadal $\mathrm{pH}$ showed no significant increase during storage $(\mathrm{P}>0.05)$, a finding that can be related to the absence of decomposition or spoilage caused by bacterial activity (HUSS, 1995).

In previous studies, final $\mathrm{pH}$ values of 6-6.3 during iced storage of some scallops adductor muscle have been reported (OCAÑO-HIGUERA et al., 2006; PACHECO-AGUILAR et al., 2008). Upon comparing the reported $\mathrm{pH}$ values of the adductor muscle and the gonad, it is clear that the levels of this parameter were less for the muscle throughout the iced storage experiments. This may be the result of the glycogen content of the two organs. For nucleotides, in table 1 it can be see that the initial value of ATP is below that reported by TSUJI \& NISHIDA (1988), who found this metabolite in a range of $0.1-0.34 \mu \mathrm{mol} \mathrm{g}^{-1}$ in the gonad of the pectinid P. yessoensis. Regarding ADP, a similar initial value was reported by TSUJI \& NISHIDA (1988), whom found values of $0.19-0.58 \mu \mathrm{mol} \mathrm{g}^{-1}$ in $\boldsymbol{P}$. yessoensis. On the another hand, initial concentrations of HxR and Hx were similar to those reported by TSUJI \& NISHIDA (1988), who found values of 0.03-0.26 and $0.07-0.58 \mu \mathrm{mol} \mathrm{g}{ }^{-1}$, respectively, in the gonads of $\boldsymbol{P}$. yessoensis. The differences observed upon comparing the concentrations of ATP and the products of its breakdown found for gonad in this experiment and the values reported for adductor muscle in previous studies (OCAÑO-HIGUERA et al., 2006; PACHECOAGUILAR et al., 2008) can be attributed to the type of tissue analyzed. Such differences have been reported by TSUJI \& NISHIDA (1988) for the pectinid $\boldsymbol{P}$. yessoensis.

The initial organisms (from the lagoon) presented a K-value of $54.10 \pm 10.23 \%$, which is higher than any report for this parameter in seafood products (SIKORSKI et al., 1990) and for value obtained from pectinids adductor muscle in previous studies (OCAÑO-HIGUERA et al., 2006; PACHECOAGUILAR et al., 2008). Moreover, upon conducting a regression analysis for the $\mathrm{K}$-value in the gonad with respect to time of storage, no adequate model of linear variation, or of any other kind, was found $(\mathrm{P}>0.05)$. Based on regression analysis, plus the high values found from the beginning of the study, it was considered that the $\mathrm{K}$-value is not a recommendable parameter for determining the quality of the gonad. It should also be noted that this parameter has not been reported as an indicator of freshness in any similar product. Differences in the useless of K-value as freshness indicator in gonad when compared with muscle may be due to the distinct energetic biochemistry between both tissues.

Determining TVB-N allowed us to quantify the low molecular weight volatile bases and amino compounds produced by the microbial 
decarboxylation of amino acids and nitrogenated compounds, which are widely used as indicators of shelf life and, more specifically, to measure stages of deterioration or loss of freshness. According to SAKAGUCHI et al. (1982), the increase of TVB-N observed at day 2 and 3 may be due primarily to the formation of low molecular weight amine compounds such as TMA-N, dimethylamine, and ammonia. Hence, according to the NOM-029-SSA1-1993 norm, and taking into account only this parameter as an indicator of quality, in the case of the gonad it could be concluded that it is not apt for human consumption starting from $3^{\text {rd }}$ of storage. It is important to note that there are no reports regarding this indicator in the gonad, but that upon comparing it with the values found in the adductor muscle in others studies (OCAÑO-HIGUERA et al., 2006; PACHECOAGUILAR et al., 2008), these values must be deemed very high, even for organisms that are supposed to be of good quality, such as those obtained and sampled directly from the culture system.

TMA-N is another indicator that is commonly used to evaluate bacterial deterioration in seafood products. TMA-N results indicate only a low level of bacterial activity during refrigerated storage, which point out that the product is apt for human consumption. It is important to emphasize that the TMA-N values present no relation to those of TVB-N that might allow us to explain the behavior and high values of this indicator $(r=0.35, \mathrm{P}>0.05)$. Given the foregoing, the gonad can be considered edible despite the fact that it exceeds the maximum permissible limit for TVB-N, as this may be the result of a process that is endogenous to this particular tissue. Added to this, microbiological analyses demonstrate the innocuity of the product and adequate conditions used in the handling of the organisms throughout the experiment.

\section{CONCLUSION}

According to the analyses performed, the gonad can be considered edible until day 4 under the conditions of transport and storage utilized in the study. These results can be achieved by maintaining the cold chain and hygienic conditions of the organisms right from the moment they are harvested and until their commercialization. In addition, the importance of promoting consumption of this organ must be considered, as it is a source of the principal essential omega 3 fatty acids. The results show that neither the K-value nor TVB-N are appropriate indicators for determining quality and freshness of the gonad of N. subnodosus.

\section{ACKNOWLEDGEMENTS}

This study is part of the thesis work to obtain the FC degree of Nathaly Montoya Camacho in the Departamento de Ciencias Químico Biológicas (Universidad de Sonora). Appreciation to the Consejo Nacional de Ciencia y Tecnología by financing the project 59898 for carrying out this study, CIBNOR and Marimex del Pacífico for supporting this research. The authors thank Ramón García Arce for his technical assistance during samples harvest.

\section{REFERENCES}

AOAC (ASSOCIATION OF OFFICIAL ANALYTICAL CHEMISTS). Official methods of analysis of the AOAC. 17 ed. Washington, DC, 2002. 2200p.

CASTRO-GONZÁLEZ, M.I. Ácidos grasos omega 3: beneficios y fuentes. Interciencia, v.27, n.3, p.128-136, 2002. Available from: <http://www.redalyc.org/articulo.oa?id=33906605>. doi: 10.1046/j.1365-2621.2003.00707.x.

DE LEONARDIS, A.; MACCIOLA, V. Effectiveness of caffeic acid as an anti-oxidant for cod liver oil. International Journal of Food Science Technology, v.38, p.475-480, 2003. Available from: $<$ http:// onlinelibrary.wiley.com/doi/10.1046/j.1365-2621.2003.00707.x/ pdf>. doi: 10.1046/j.1365-2621.2003.00707.x.

HINTZE, J. NCSS and PASS, number cruncher statistical systems. Kaysvill, Utah, 2001. Available from: <http://www.ncss.com>.

HUSS, H.H. Quality and quality changes in fresh fish. Rome Italy: FAO, Food and Agriculture of the United Nations, 1995. 202p. (Fisheries Technical Paper 348).

NOM-029-SSA1. Bienes y servicios. Productos de la pesca. Crustáceos frescos-refrigerados y congelados. Especificaciones sanitarias. México: Secretaría de salud, 1994. 26p.

NOM-031-SSA1. Bienes y servicios. Productos de la pesca. Moluscos bivalvos frescos-refrigerados y congelados. Especificaciones sanitarias. México: Secretaría de salud, 1993. $26 \mathrm{p}$.

OCAÑO-HIGUERA, V.M. et al. Bioquímica posmortem en pectínidos. In: MAEDA-MARTÍNEZ, A.N. (Ed.). Los moluscos pectínidos de Iberoamérica: ciencia y acuicultura. México: Editorial Limusa S.A. de C.V., 2001. p.405-429.

OCAÑO-HIGUERA, V.M. et al. Postmortem biochemical and textural changes in the adductor muscle of catarina scallop stored at $0^{\circ} \mathrm{C}$. Journal of Food Biochemistry, v.30, p.373389, 2006. Available from: <http://onlinelibrary.wiley.com/ doi/10.1111/j.1745-4514.2006.00071.x/pdf>. doi: 10.1111/j.17454514.2006.00071.x.

PACHECO-AGUILAR, R. et al. Postmortem changes in the adductor muscle of Pacific lions-paw scallop (Nodipecten subnodosus) during ice storage. Journal of Food Chemistry, v.106, p.253-259, 2008. Available from: <http://www. sciencedirect.com.biblioteca.ciad.mx:2048/science/article/pii/ S0308814607005419>. doi: 10.1016/j.foodchem.2007.05.079.

PALACIOS, E. et al. Lipid composition of the Pacific lion-paw scallop, Nodipecten (Lyropecten) subnodosus, in relation to 
gametogenesis. I. Fatty acids. Aquaculture, v.250, p.95-101, 2005. Available from: <http://www.sciencedirect.com.biblioteca.ciad. mx:2048/science/article/pii/S0044848607001640>. doi: 10.1016/j. aquaculture.2007.02.030

PAUST, B.C.; RICE, A.A. Marketing and shipping live aquatic products. In: Proceedings of the second international conference and exhibition. Fairbanks. Fairbanks. Seattle, WA: University of Alaska Sea Grant, AK-SG-01-03, 2001.311p.

RACOTTA, I.S. et al. Comparative biochemical composition of ploidy groups of the lion-paw scallop (Nodipecten subnodosus Sowerby) supports the physiological hypothesis for the lack of advantage in triploid mollusc's growth in food-rich environments. Marine Biology, v.153, p.1245-1256, 2008. Available from: $<$ http://link.springer.com/article/10.1007/s00227-007-0897-4>. doi: $10.1007 / \mathrm{s} 00227-007-0897-4$

RYDER, J.M. Determination of adenosine triphosphate and its breakdown products in fish muscle by high performance liquid chromatography. Journal of Agricultural and Food Chemistry, v.33, p.678-680, 1985. Available from: <http://pubs.acs.org/doi/ abs/10.1021/jf00064a027>. doi: 10.1021/jf00064a027.
SAITO, T. et al. A new method for estimating the freshness of fish. Bulletin of the Japanese Society for the Science of Fish, v.24, n.9, p.749-750, 1959. Available from: <https://www.jstage.jst. go.jp/article/suisan1932/24/9/24_9 749/_article>.

SAKAGUCHI, M. et al. Changes in free amino acids and creatine contents in yellowtail (Seriola quinqueradiata) muscle during ice storage. Journal of Food Science, v.47, p.1662 1666, 1982. Available from: <http://onlinelibrary.wiley.com/ doi/10.1111/j.1365-2621.1982.tb05006.x/pdf>. doi: 10.1111/ j.1365-2621.1982.tb05006.x.

SIKORSKI, Z.E. et al. Postharvest biochemical and microbial changes. In: SIKORSKI, Z.E. (Ed.). Seafood: resources, nutritional composition and preservation. FI, USA: CRC, 1990. p.55-75.

TSUJI, K.; NISHIDA, H. Seasonal changes in biochemical composition of the scallop Patinopecten yessoensis in Nemuro Bay, Hokkaido. Scientific Reports of the Hokkaido Fisheries Experimental Station, v.31, p.27-54, 1998.

WOYEWODA, A.D. et al. Recommended laboratory methods for assessment of fish quality. Nova Scotia, Canada: Technical University of Nova Scotia, 1986. 143p. 